Article

\title{
Ecosystem Engineering by Thalassinidean Crustaceans: Response Variability, Contextual Dependencies and Perspectives on Future Research
}

\author{
Deena Pillay \\ Marine Research Institute, Department of Biological Sciences, University of Cape Town, Private Bag X3, \\ Rondebosch 7701, Cape Town, South Africa; Deena.pillay@uct.ac.za
}

Received: 18 March 2019; Accepted: 15 April 2019; Published: 19 April 2019

\begin{abstract}
Ecological functions in marine sedimentary habitats are greatly influenced by bio-engineering organisms. Thalassinidean crustaceans are particularly important in this regard, given their density, spatial occupancy and burrowing depths. These features coupled with high per capita engineering rates (bioturbation mainly) and the ability to modulate multiple resources simultaneously, place thalassinids amongst the most influential of ecosystem engineers in marine ecosystems. Research on these organisms has focused on mechanisms by which engineering effects are propagated, whilst drawing attention to the impact of ecosystem modification on ecological processes. However, disparities in the outcomes of global research suggest that complex dependencies underpin ecological responses to thalassinideans that we do not yet fully understand. It is in this context that this review draws attention to some of the dependencies in question, specifically by using existing models and hypotheses to (i) demonstrate how these dependencies can alter ecological responses to ecosystem engineering by thalassinids, and (ii) explain variability observed in outcomes of existing research. This review also shows the potential for explicit inclusion of such dependencies in future research to generate new knowledge on thalassinidean ecosystem engineering, from both fundamental and global change perspectives. More broadly, this review is a contribution towards advancing a predictive and mechanistic understanding of thalassinidean ecosystem engineering, in which biotic and abiotic dependencies are integrated.
\end{abstract}

Keywords: bioengineering; soft-sediments; contextual dependencies; resource flows; community responses; endobenthic

\section{Introduction}

Ecosystem engineering - the process by which organisms alter resource availability and flows to sympatric species [1], is a central determinant of community structure and ecological functioning in marine sedimentary systems [2,3]. Burrowing organisms are recognised for their roles as ecosystem modifiers, but endobenthic crustaceans are arguably the most dominant engineers in marine sedimentary systems [4-6]. In the past, these crustaceans have been referred to as 'thalassinids' or 'thalassinideans', due to their classification within the infra-order Thalassinidea $[7,8]$. However, subsequent taxonomic revisions have split the group into two infraorders- the Axiidea and Gebiidea $[9,10]$. For convenience, and because the group is well-recognised and established in the literature, the terms 'thalassinideans' or 'thalassinids' will be used interchangeably in this review, while still recognising that the group is paraphyletic.

Thalassinidean crustaceans modify marine sedimentary systems at levels that are probably unmatched by other benthic engineering species [6], resulting in conspicuous and complex alterations to benthic habitats (Figure 1). This is due primarily to these crustaceans occurring at high densities, 
occupying very large areas of the benthos, burrowing up to depths of $1 \mathrm{~m}$ and beyond and having some of the highest known per capita engineering rates (mainly due to sediment and porewater movement) of known benthic engineers [4-6]. These features, coupled with the large number of resources and abiotic processes they affect simultaneously, result in thalassinidean crustaceans being amongst the most influential of ecosystem engineers in marine benthic ecosystems [4-6].

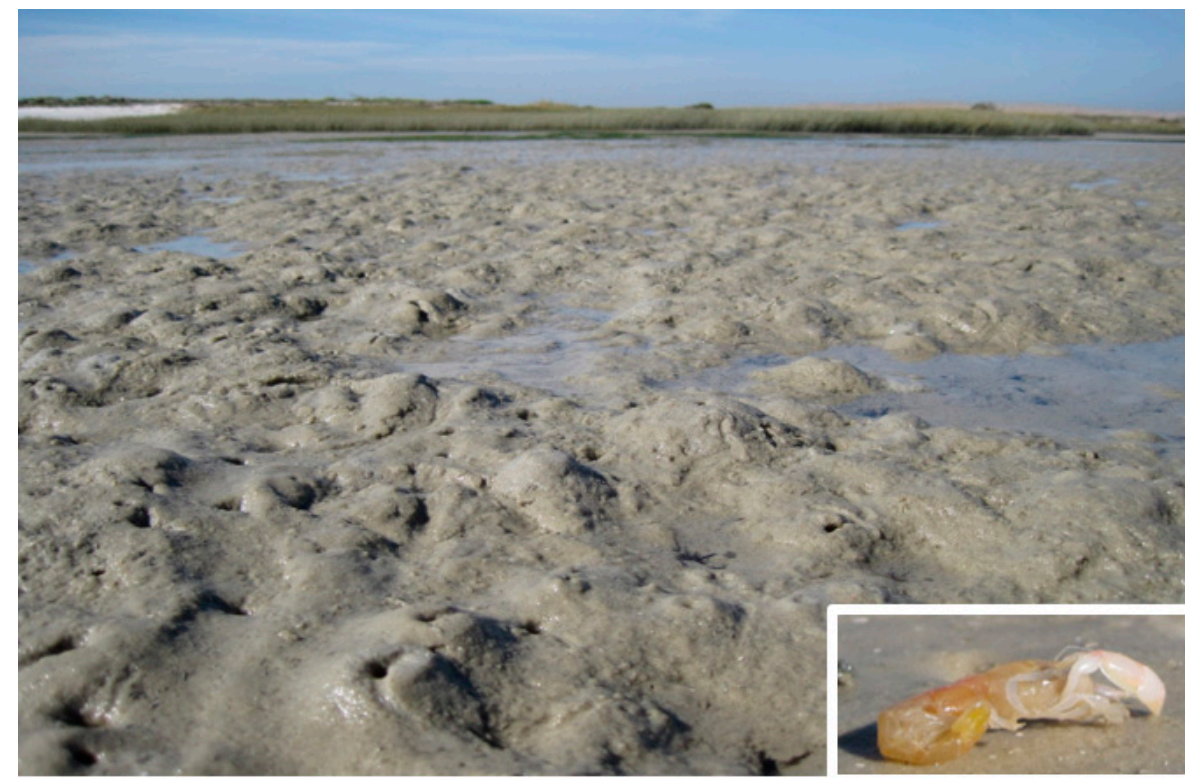

Figure 1. Irregular sediment topography created by engineering activities of the sandprawn Callichirus [as Callianassa] kraussi in Langebaan Lagoon, on the west coast of South Africa. Mid-shore sandflats are shown in the foreground and high-shore marshes in the background. Photos courtesy of Jessica Dawson.

The scale and intensity at which thalassinideans alter biotic and abiotic processes in benthic ecosystems has resulted in these engineers receiving significant research attention [6], with studies generally being motivated by a need to understand their broader role in community organisation and ecosystem functioning. In this context, research has generally sought to quantify the strength of engineering effects induced by thalassinidean species on biotic and abiotic processes. Such studies have been based on a range of approaches including field and laboratory experiments and in situ comparisons across contrasting engineering states in space and time [6]. From a biotic perspective, studies have documented the responses of sympatric communities across a wide size spectrum (microscopic bacteria to macroscopic fish) [11-13] and across multiple organisational levels (individuals to ecosystem) [6], while research on abiotic responses has examined nutrient fluxes, gaseous exchange and sediment and porewater characteristics [6,14-20]. In the majority of cases, studies have emphasised the strength with which thalassinidean crustaceans engineer benthic ecosystems, while shedding light on fundamental processes that are affected concomitantly. Cumulatively, these studies have contributed to the generation of broad hypotheses to advance a mechanistic understanding of how engineering-induced effects manifest [6].

From a biotic perspective, there are two broad hypotheses that are relevant to understanding ecosystem engineering effects by thalassinidean crustaceans, though it must be pointed out that these have been based largely on work on deposit-feeding species while- equivalent work for filter-feeders has been neglected [6]. The first hypothesis is that thalassinids induce amensalistic effects on surface-associated assemblages through rapid sediment turnover [6,21-27]. Amensalism is thought to occur via a host of indirect effects linked to increasing colonisation and feeding constraints and risk from enemy attack mediated by sediment turnover $[26,28]$. Constraints on colonisation have been linked to sediment turnover inhibiting microbial colonisation of surficial sediments, which in turn limits biofilm development and hence invertebrate recruitment [29]. Sediment turnover may also reduce 
trophic resource (bacteria, microalgae) availability for epibenthic feeders [13,26]. For filter-feeding taxa, it has been suggested that turned-over sediment and subsequent resuspension interferes with filtration organs, leading to feeding costs and metabolic losses $[26,27]$. This notion is an extension of the trophic-amensalism hypothesis put forward in the seminal work of Rhoads and Young [30], which attempted to explain spatial patterns of segregation between deposit- and filter-feeding assemblages.

The second general hypothesis emerging from studies on biotic effects of thalassinideans (again, mainly deposit-feeders) is that engineering will either have neutral or facilitative effects on burrowing infauna [6,31-35]. The latter is due to oxygenation and loosening of sediments by thalassinid burrowing [6,31-35], but also due to burrow walls being enriched in trophic resources (microalgae, bacteria and mucopolysaccharides) $[6,11,36-38]$. Such enrichment may be driven by the addition of mucus to burrow walls and excretion of nutrients, which can create fertile conditions for microbial proliferation [6]. Passive adsorption of phytoplankton, bacteria and other organic material onto burrow walls during ventilation may also explain the propensity of burrow walls to function as hot-spots for microbial activity [6]. In combination, the two broad hypotheses presented here (amensalistic effects on epifauna; neutral/positive effects on infauna) lead to a general paradigm that endobenthic thalassinideans (mainly deposit-feeding species) engineer benthic systems by shifting habitat utilisation away from the sediment-water interface and deeper into sediments [6].

While this paradigm provides a valuable framework for understanding biotic/community responses to thalassinidean engineers, it should be apparent from existing literature that deviations from this paradigm are conspicuous (reviewed in detail in [6]). For example, while several studies have supported the idea that burrow walls of various thalassinids are hotspots for microbial activity [11,36-38], others have not [39]. Similar contrasts in response outcomes have been recorded for burrow wall meiofauna [37,40,41] seagrasses [33,42,43] and benthic macrofaunal assemblages [6]. In South Africa, studies on ecosystem engineering by the sandprawn Callichirus (as Callianassa) kraussi at different localities have yielded contrasting results. Negative effects on microalgal biomass were recorded from in situ inclusions of sandprawns in Durban Bay [29], on the sub-tropical east coast, along with declines in some macrofaunal community metrics (abundance, richness) [27]. However, sandprawn inclusion had no discernible effect on these variables in studies conducted in the Kasouga Estuary [44], in the warm-temperate east coast, despite this study following an apparently identical experimental design to that employed in Durban Bay. Some of the above-listed deviations from expectations are inevitably driven by methodological differences, but some are likely a product of disparities in abiotic settings in which the studies were conducted, and/or biological aspects of focal thalassinideans and sympatric assemblages.

Taken collectively, variability in biotic responses to engineering by thalassinid crustaceans suggests that complex ecological processes underlie emergent engineer impacts on benthic ecosystems. The need to develop deeper insights into these processes that we do not yet fully understand forms the fundamental motivation for this review. More specifically, this review draws attention to broader processes and dependencies that can influence ecological responses to ecosystem engineering by thalassinids, but it also illustrates how these dependencies can clarify some of the variability observed in the outcomes of global research on the topic. More broadly, this review advocates for the development of a mechanistic and integrative understanding of ecosystem engineering by thalassinideans, in which aspects of the engineer, responding assemblages and the environment are explicitly considered and incorporated into future studies (as summarised in Figure 2). This in turn will likely assist in improving predictive abilities across a wider range of ecological settings. Ultimately, this review makes a contribution towards growing understanding of ecosystem engineering by a globally important group of endobenthic organisms. 

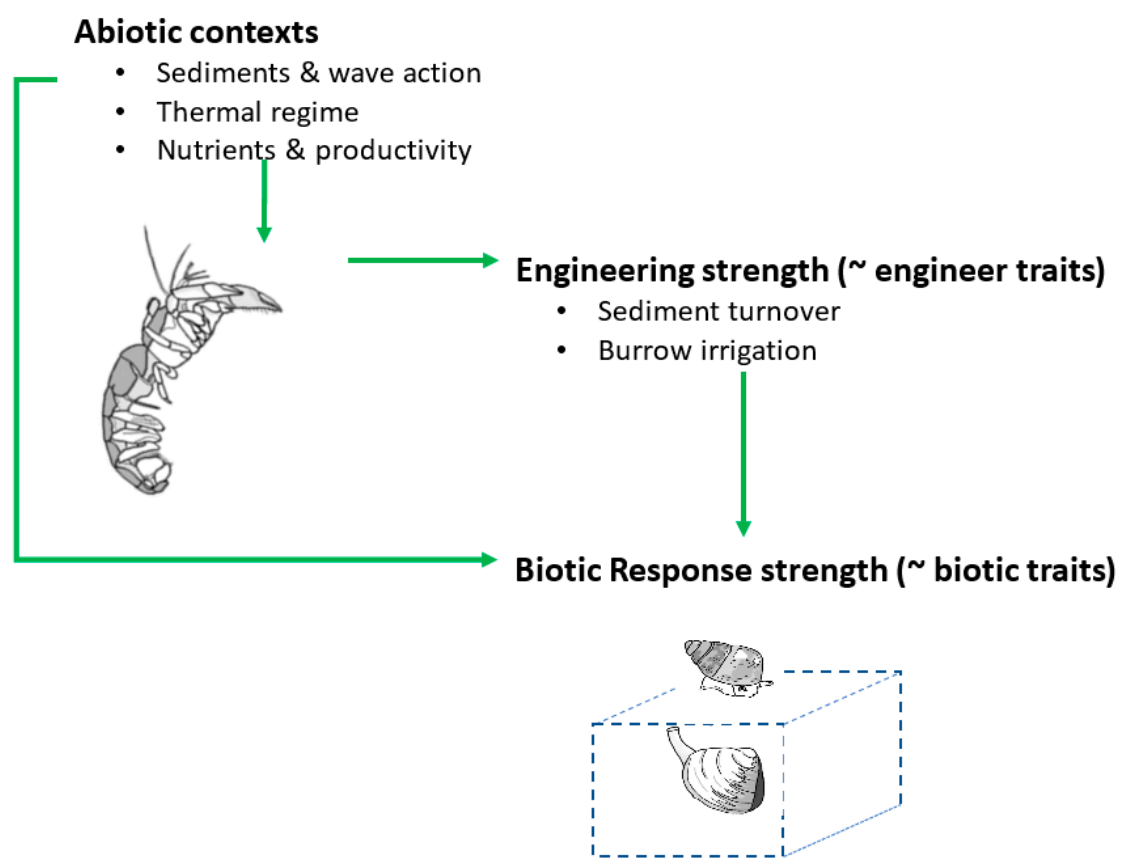

Figure 2. Schematic overview of dependencies that can influence biotic responses to engineering by thalassinidean crustaceans. Abiotic contexts such as sedimentary and thermal regimes influence engineer traits, which in turn determine the strength of abiotic modification, principally by affecting sediment turnover and burrow irrigation. However, fundamental traits of thalassinids determine the degree to which they are influenced by abiotic settings. Community level responses are affected by abiotic contexts and the strength of ecosystem engineering, which are all influenced by biological traits of assemblages. The need to understand and integrate these aspects in future research form the central motivation for this review. Animal drawings courtesy of Jessica Dawson.

\section{Contextual Processes/Variables}

The forthcoming sections discuss in detail some of the contextual processes and dependencies that are likely to influence responses to ecosystem engineering by thalassinidean crustaceans. These discussions focus on biological responses, but within a general framework of contemporary hypotheses and conceptual models that are used to explain biotic responses to thalassinid bioengineering. However, the central motivation for this review and the forthcoming discussion are equally applicable and relevant to understanding responses of abiotic processes to engineering by thalassinids. Thus, the ideas expressed in this review are relevant to all researchers interested in ecosystem engineering by burrowing thalassinids, not only to those with biological inclinations. The concepts presented in this review complement a prior review on thalassinid engineering [6], in which emphasis was placed on net engineering effects. This review builds on the above-mentioned review by drawing attention to contextual dependencies and processes that can impact thalassinidean ecosystem engineering.

\subsection{Engineer Density}

It is well-established that engineer density is fundamental in determining the magnitude and direction of engineering effects on resource flows and biotic responses [1]. This is because density influences the strength of engineering per unit area by scaling up per capita engineering effects [1]. At a global level, studies on engineering effects of thalassinideans have been based on widely contrasting engineer densities, which presumably reflects interspecific and geographical variability in natural thalassinidean densities across localities in which studies were undertaken. In South Africa for example, in situ exclusion and inclusion experiments on sandprawn (Callichirus (as Callianassa) kraussi) ecosystem engineering have been based on densities ranging from $40 / \mathrm{m}^{2}$ in the Kosouga Estuary 
(warm temperate east coast) [44] to $120 / \mathrm{m}^{2}$ in Durban Bay (subtropical east coast) [27]. Given the range of engineer densities used across studies in the literature, variability in engineer density is potentially a significant driver of variation in the strength and direction of biotic responses to ecosystem engineering by thalassinideans.

The notion that differences in thalassinidean density can cause variability in community-level responses stems ultimately from the fact that these organisms, like all engineers, create new biological resources and/or increase the availability of existing resources (e.g., burrows create new microhabitats for infauna and may be enriched with trophic resources) while simultaneously destroying others and/or reducing their availability (e.g., sediment turnover destroys epibenthic microhabitats) [45]. Such contrasting effects on resources can elicit positive or negative responses from particular biotic groups, depending on fundamental biological traits that either positively or negatively predispose them to abiotic modification $[2,3,6,45]$. However, even within organismal groups with contrasting sensitivities to ecosystem engineering, both positive and negative effects can manifest at either high or low thalassinid density. This is due to the strength of resource creation and destruction (and/or increases or decreases in availability) by thalassinids and organismal tolerance to engineering being density-dependent [1]. For example, organismal groups that are generally regarded as being intolerant to thalassinid ecosystem engineering may be positively affected at low thalassinid densities, due to resource destruction being weak but resource creation being stronger and beneficial. Thus, responses of organism groups are likely to be non-linear and unimodal in relation to increasing thalassinid densities. Such responses are illustrated in Figure 3A, which shows the expected effects of increasing thalassinidean densities on epifaunal and infaunal diversity and/or abundance. Both metrics for epifauna are generally expected to be negatively impacted by sediment reworking by thalassinids, which is consistent with most contemporary ideas on deposit-feeder effects on epifauna $[2,3,6,30]$. However, at very low densities, thalassinids may generate positive effects on epifauna by, for example, increasing nutrient fluxes and hence surface productivity [46]. Beyond this point, though, further increases in thalassinid density should induce declines in epifaunal metrics [2,3,6,30]. In contrast, infaunal metrics should generally display the opposite pattern, with metrics generally increasing with thalassinid densities up to a threshold density, beyond which negative effects manifest [3,6,31-35]. It must however be acknowledged that the development of antagonistic interactions between thalassinideans at high densities could lead to deviations from the predictions outlined above.

Whole-community metrics such as species richness are likely to show similar non-linear, unimodal responses to increasing thalassinid density, based on the mechanisms proposed above. At low thalassinidean densities, ecosystem engineering may generate stimulatory effects on richness, due to positive effects on resource flows outweighing negative effects. However, beyond some hypothetical density threshold, values should decrease (Figure 3B). This decrease is likely generated initially by amensalistic effects on epifauna [2,3,6,30], but at very high thalassinid densities, additional negative effects on infauna may emerge due to abiotic conditions created by engineering selecting for a subset of infauna [3]. Also likely is that at the upper end of density limits, thalassinid ecosystem engineering would cause richness to decrease to levels below non-engineered states. This is primarily due to engineering creating abiotic conditions that can be tolerated by some taxa [3].

The non-linear responses displayed in Figure 3 provide a simple, yet useful framework for understanding how differences in engineer densities may elicit variable community responses to thalassinid engineering. At low densities, combined per capita engineering effects are probably insufficient to create abiotic conditions that are dissimilar to non-engineered states, resulting in there being insufficient impetus for a switch in community structure to occur. However, at the opposite end of the density spectrum, a switch in community structure is very likely, as cumulative per capita effects radically alter abiotic properties and processes. In the context of experimental and comparative studies, at low thalassinid densities, biological responses would probably be statistically indistinguishable between non-engineered ( - thalassinideans) and engineered (+ thalassinideans) states, but strong differences should occur at the higher end of the density range, with large changes in community 
structure brought on principally by shifts from epifaunal to infaunal dominance. In support of this notion, Henninger and Froneman [44] suggested that the negligible effects of sandprawn (Callichirus [as Callianassa] kraussi) ecosystem engineering on community structure in the Kasouga Estuary (Eastern Cape of South Africa) was likely a product of the low sandprawn densities $\left(40 / \mathrm{m}^{2}\right)$ used in their experiment. In contrast, the higher sandprawn densities $\left(120 / \mathrm{m}^{2}\right)$ on which experiments in Durban Bay (KwaZulu-Natal, South Africa) were based yielded very different results, with statistically discernible differences in community structure between engineered and non-engineered states, with a shift to epifaunal dominance in the absence of sandprawns being prominent [27].
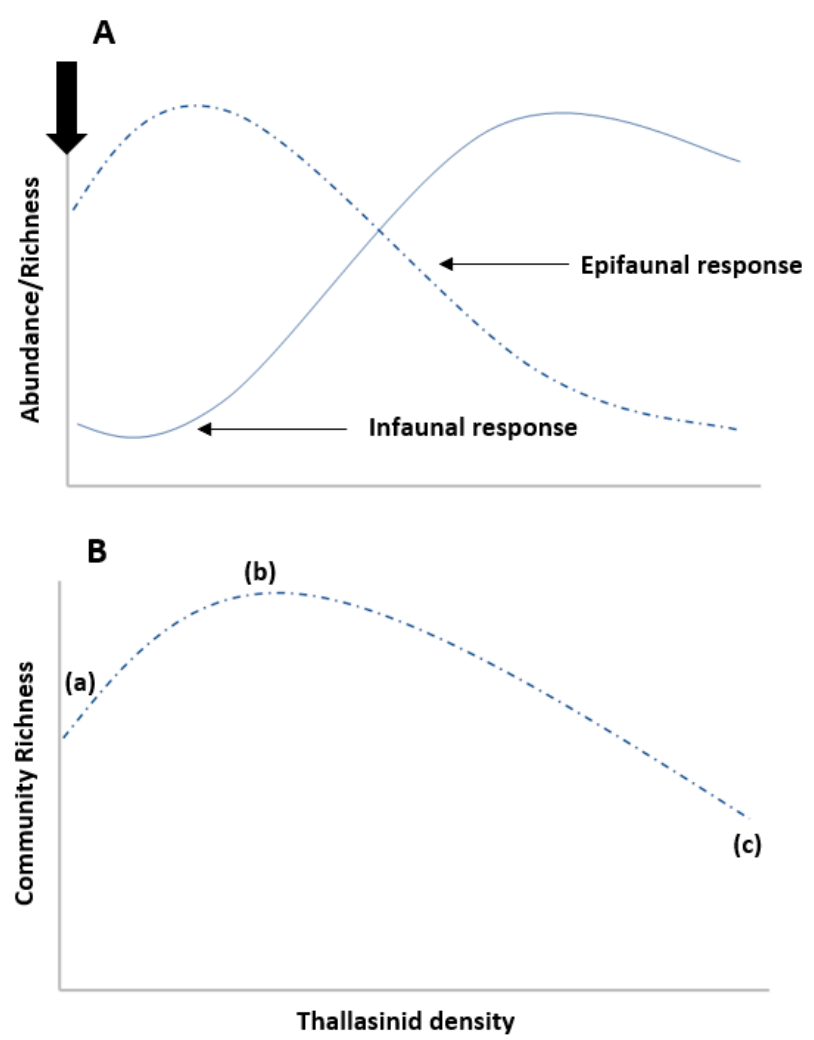

Figure 3. Predicted responses of (A) epi- and infaunal abundance/richness and (B) community richness to increasing thalassinid densities. In A, increasing thalassinid densities is expected to induce shifts from epifaunal- to infaunal-dominated states, due to increased sediment processing strengthening amensalism and facilitation on epifauna and infauna respectively. In (B), community richness is expected to respond unimodally to increasing thalassinid density. Thick arrow above y-axis denotes a non-engineered state. Note: responses are intended to be illustrative, not exhaustive - broad patterns are more important than specific response features.

Non-linearity in responses of community metrics such as abundance and richness to thalassinid density may also explain variability in their responses in global case studies. This is illustrated in Figure 3B, which shows the expected response of community richness to increasing engineer density, in which three points along the density spectrum are overlain. If the engineer density used in studies is low (Point ' $a$ ' in Figure 3B) and not dissimilar to that of the non-engineered state, then comparisons between engineered and non-engineered conditions would probably yield insignificant findings. If engineer densities used in studies approach theoretical threshold densities at which responses peak (Point ' $b$ ' in Figure 3B), then the outcome of comparisons between engineered and non-engineered states would be positive, leading to an interpretation of engineering having stimulatory effects. However, the opposite would occur were upper density extremes (Point ' $c$ ' in Figure 3B) to be used. Collectively, the scenarios depicted in Figure 3B illustrate how variation in thalassinid densities can account for 
differences in the direction (positive, negative, neutral) and magnitude of outcomes in studies on thalassinid ecosystem engineering.

The points raised in this section regarding engineer density and non-linearity in the responses induced highlight a few important considerations for future research in the field. The first point is that findings of studies on biotic responses to thalassinid ecosystem engineering need to be contextualised against the known density ranges of engineering species being investigated (based on literature, for example). The advantage of contextualising thalassinid densities when interpreting findings is that it prevents liberal extrapolations and broad generalisations on ecological function. Contextualisation also develops an appreciation that ecological responses recorded under a particular density regime does not guarantee the same response under a different density regime even under similar environmental conditions. Secondly, future studies, particularly experimental ones, would benefit by shifting emphasis from testing thalassinid presence/absence effects to tests of responses across a density spectrum. This would provide robust data on ecological response patterns and thresholds, thus broadening understanding of the functional relevance of thalassinid species beyond presence alone.

\subsection{Engineer Traits}

It is well recognised that organismal traits strongly influence the strength of biological interactions [47]. The idea that engineer traits can influence the direction and magnitude of biotic responses to ecosystem engineering is therefore not entirely surprising, since responses are influenced to a large degree by the strength of abiotic modification by individual engineers, which in turn is driven by specific biological traits that they possess [1,48]. In terms of thalassinidean crustaceans, variability in biological traits across groups is conspicuous [6]. Life-history traits, for example, are highly variable with several species typically having five or six planktonic zoeal stages, followed by a benthic megalopa or decapodid larval stage. Some species have abbreviated larval stages, with two zoeal phases (Lepidophthalmus [8,49]; Austinogebia (as Upogebia) edulis; [50]). In Callichirus (as Callianassa) kraussi, planktonic larval stages are lost, and newly hatched juveniles form branches off main parent burrows [51].

Of all traits exhibited by thalassinids, variation in feeding behaviour is potentially the most significant driver of variability in the strength of biotic responses to ecosystem engineering. This is because feeding behaviours in thalassinids are intimately linked with two fundamental and distinct pathways by which their engineering effects are propagated viz. sediment turnover/reworking and porewater fluxes across the sediment-water interface [6]. Deposit-feeding thalassinideans feed by stripping organic material from burrow sediments and depositing residual material on the sediment surface. Thus, feeding rate probably correlates well with sediment-turnover rate. Filter-feeding groups on the other hand, extract organic material from water that is actively pumped through burrow systems [52]. Based on both feeding methods, a range of trophic resources are consumed, including microalgae, bacteria, seagrass, mangrove and saltmarsh debris, meiofauna and macrofauna [53-55]. In addition, some taxa have been described as gardeners, due to their behaviour of attaching plant and other debris to burrow walls to stimulate microbial growth, on which they feed [56]. Some also have specialised chambers where plant material is stored, likely for feeding purposes [57].

At a broad classification level, disparities in feeding behaviours can explain differences in pathways by which engineering effects are propagated. Deposit-feeding taxa generate impacts mainly through sediment turnover and reworking, while filter feeding groups are unlikely to have significant sediment-mediated influences on biotic processes, but changes driven by bi-directional movement of burrow waters may be significant [6]. However, within this broad classification scheme, substantial variability exists, with some members being specialists and others using a combination of both deposit and filter-feeding methods [58]. Within deposit-feeding taxa, variability in foraging behaviours can potentially induce differential biotic responses to ecosystem engineering. This stems from the fact that variability in sediment processing effort, which relates closely to the degree of deposit-feeding specialisation, likely influences the quantities of sediment turned over to the 
sediment-water interface [59] and therefore the strength of amensalistic effects generated on epifauna. The degree of deposit-feeding specialisation also likely influences the level of sediment loosening and oxygenation, which can alter the strength of facilitation on infaunal assemblages [6]. These ideas are summarised in Figure 4, which shows expected responses of epibenthic and infaunal assemblages to increasing densities of thalassinid engineers that display contrasting sediment processing behaviours. In thalassinid species that exhibit high sediment processing and turnover rates, amensalistic effects on epifauna are likely to emerge at lower engineer densities, due to negative effects of sediment turnover manifesting at a relatively low density (Figure 4A). Similarly, facilitative effects on infauna probably emerge at lower thalassinid densities when their sediment turnover rates are high, due to accelerated rates of sediment loosening coupled with increased trophic resources in burrows (Figure 4B) Therefore, one potential outcome of ecosystem engineering by thalassinids that display high sediment processing activities, is that a switch from epifaunal to infaunal dominance may be induced at lower engineer densities.
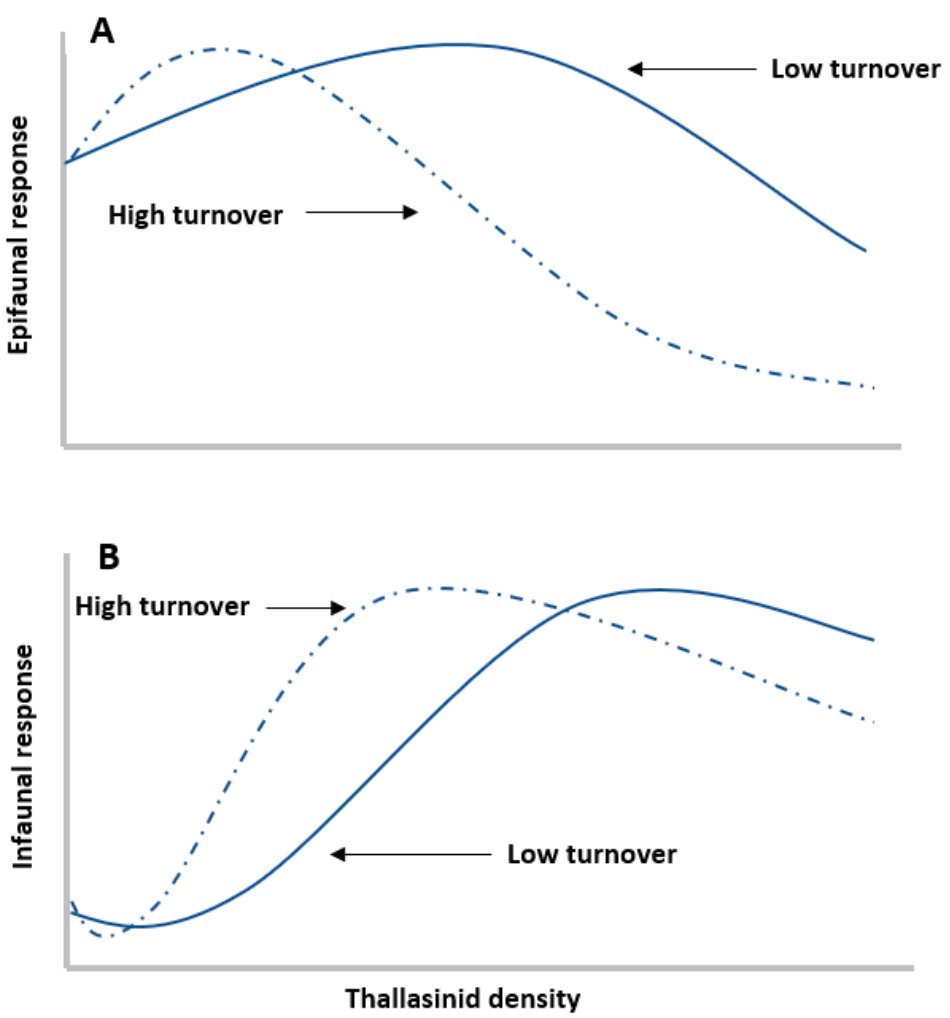

Figure 4. Predicted responses of (A) epifauna and (B) infauna to increasing densities of two deposit-feeding thalassinid species that exhibit contrasting sediment processing behaviours. Species that exhibit high turnover (broken lines) rates induce changes in direction of infaunal and epifaunal responses at lower densities than those that exhibit low turnover (solid lines). Note: responses are intended to be illustrative, not exhaustive - broad patterns are more important than specific response features.

While plasticity in sediment turnover and reworking activities is a strong feature of thalassinid ecosystem engineering [58-60], thalassinids also display variability in burrow lining and compaction behaviour [6]. This aspect is another trait of thalassinideans that can alter the strength of their engineering effects, particularly for infauna. It has been suggested that some thalassinideans compact and line their burrows with fine sediments [6,37], probably for reasons relating to stabilisation. However, it has also been suggested that this behaviour may negatively impact some biota resident along burrow wall habitats, since burrow lining and compaction reduces sediment pore spaces available for movement of interstitial organisms [37]. The implication of such behaviour is that while burrow 
walls may function as "hotspots" for trophic resources such as bacteria and algae [11,36-38], positive, bottom-up effects on adjacent infauna may not materialise due to compaction and burrow lining limiting organismal access [37], even though burrowing provides other benefits such as sediment loosening and oxygenation. Thus, accurate predictions of thalassinid effects on infauna may require knowledge of burrow lining and compaction behaviour, in addition to sediment processing capabilities. More broadly, burrow compaction may also influence hydraulic pressures generated by thalassinids, and therefore, bio-irrigation efficiency.

\subsection{Sediment Type and Wave Action}

Sediment characteristics are recognised broadly as important drivers of biotic and abiotic processes and properties in benthic ecosystems, since they provide much of the background context for organismal functions and interactions [61,62]. Granulometry is a particularly important sedimentary trait, influencing processes such as oxygen availability, organic matter content and porosity $[61,62]$. Often, sediment granulometry is linked to wave exposure, such that high levels of exposure generally select for coarser sediment fractions, which are in turn well-oxygenated and highly porous, but have low organic matter levels. In contrast, areas sheltered from wave action are typically finer in particle size, have low porosity and oxygenation potential, but high organic content $[61,62]$. The interplay between wave action and sediment particle size in turn has a significant influence on resident benthic assemblages; dynamic course sediments are generally dominated by burrowing infauna, while sheltered fine sediments have both epi- and infaunal components, with epifaunal components increasing in sediments with very fine fractions. In addition, richness and abundance may be lower in dynamic, course sediment environments relative to finer systems [61,62].

Given the broad patterns outlined in the preceding paragraph, wave exposure and the sedimentary contexts in which thalassinidean engineering occurs have the potential to influence how biota respond to engineering. Therefore, these variables are also likely candidates for explaining response variability across engineering studies. Research conducted in dynamic, coarse sediments, for example, would probably generate different biotic outcomes relative to fine sediments, given the contrasts in biotic attributes outlined earlier [61,62]. In coarse sediments, surficial microphytobenthic and bacterial biomass are expected to be lower than in finer sediment, due to surface instability attenuating colonisation rates and increasing resuspension [61,62]. One outcome of such instability is that in experimental or comparative studies, magnitudes of difference in microphytobenthic and bacterial biomass between engineered ( + thalassinideans) and non-engineered states ( - thalassinideans) are likely to be small or negligible (relative to finer sediments), due to the strength of habitat dynamism superseding that of thalassinidean engineering. In other words, the dynamic nature of the habitat may hinder microbial colonisation and persistence, even in the absence of ecosystem engineering by thalassinideans. Similarly, differences in epifaunal community structure and associated community metrics (diversity, abundance) are likely to be minimal, due to the dynamic nature of sediments, particularly at the upper surficial layers. Differences in infaunal assemblages would also likely be small or negligible in coarse sediments relative to finer ones. This is because while deeper sediments may be less affected by wave action and general surface instability, infaunal colonisation is likely to be negatively impacted by such instability [61,62], implying that potential positive effects of thalassinids on resource creation and/or increases in their availability [11,36-38] could be countered by a recruitment bottleneck.

In finer sediments, biotic differences between thalassinidean presence and absence should be magnified relative to coarser sediments, mainly due to environmental dynamism being weak and thus being unable to override thalassinidean ecosystem engineering strength. Thus, in finer sediments, the absence of thalassinidean engineering is likely to result in levels of epibenthic bacteria and microalgae being much greater than in sediments in which thalassinideans are present, relative to coarser sediment. Relatively stable surface sediments would also result in epifaunal assemblages in the presence of thalassinids being very different to those in the absence of thalassinids, potentially with metrics for this 
group (e.g., biomass, richness) being greater in thalassinid absence [61,62]. This disparity could also be explained by differences in levels of trophic resources (bacteria and microalgae) between thalassinid presence and absence, with higher resource levels in the absence of thalassinids leading to positive bottom-up effects on populations and possibly community metrics (e.g., greater community richness and abundance) [29]. Similar contrasts may emerge for infauna, due to habitat creation (burrows) and increased trophic resources [11,36-38]. Lastly, higher levels of bacteria and microalgae associated with thalassinid absence may stimulate epifaunal and infaunal recruitment. Prior experimental studies have shown that surface sediments with low levels of bacteria, microalgae and their exopolymeric secretions (which are major constituents of microbial biofilms) are associated with low levels of macroinvertebrate recruitment. This is mainly due to biofilm components acting as settlement cues for invertebrates and functioning as sediment stabilisers and/or trophic resources for recruits [29]. Experiments have also shown that high densities of thalassinids can limit biofilm development and recruitment [29].

The points raised in this section point to sediment traits being potentially important contextual variables that can shed light on response variability to thalassinid bioengineering. This may be the case at a local South African level, where almost identical experiments on engineering by burrowing sandprawns yielded very different outcomes. The study of Henninger and Froneman [44] took place in the mouth region in an estuary (Kasouga Estuary) during a period when it was closed off from the sea, while the study of Pillay et al. [27] took place in sheltered intertidal sandflats of a marine embayment. While specific details of the benthic environment in the respective studies are lacking, it can be deduced based on local knowledge and existing literature that the sedimentary contexts in which these studies were conducted were likely very different. Substrates in the mouth regions of estuaries are much coarser, given the dynamic nature of the habitat, whereas sediment in sandflats is finer due to their sheltered nature [61,62]. Thus, the lack of major effects of the sandprawn Callichirus (as Calianassa) kraussi on community metrics, individual taxa and microalgal biomass in the Kasouga study may potentially be linked to the dynamic and coarser nature of the benthos, whereas large declines in abundance of individual taxa, community metrics, microalgal biomass and epibenthic taxa may be related to shelter from wave action and finer sediments in the Durban Bay study.

While the preceding paragraphs have emphasized the role of sedimentary characteristics in driving assemblage differences, and its potential role in mediating the strength of thalassinid ecosystem engineering, predicting thalassinid engineering effects across contrasting sedimentological contexts is complicated by the fact that sediment attributes are likely to additionally influence thalassinid behavioural traits. Such sediment-mediated shifts in behaviour can have important implications for the strength of ecosystem engineering activities such as sediment turnover and burrowing. While there have been few explicit tests of this within thalassinid-related studies, the potential for sediment-mediated shifts in thalassinid behaviour to alter ecological responses can be inferred from studies elsewhere. Needham et al. [63] for example, demonstrated that the burrowing activities of the crab Austrohelice crassa is modified by sediment attributes. Specifically, sediment reworking by A. crassa was increased 16-fold in sandy sediment relative to more cohesive sediment (i.e., with a greater silt-clay content), with burrow: crab ratios and burrow durability being greater in the latter sediment type. Thus, developing an understanding of how variability in sedimentary contexts influence ecosystem engineering by thalassinids may require knowledge of potential sediment-mediated shifts in engineer behaviour over-and-above changes to sympatric biotic assemblages mediated by sediment traits.

\subsection{Temperature}

Environmental temperature is arguably the most influential determinant of organismal biology, influencing processes such as metabolism and nutrition [64]. Temperature is a particularly important contextual variable for ectothermic species, since they are unable to regulate internal body temperatures, and thus, passively conform to ambient thermal conditions [64]. In such species, physiological performance and behaviour are strongly affected by ambient temperature, with increasing temperature causing both positive and negative effects at the organismal level on either side of thermal optima [64]. 
In addition to direct temperature effects on organismal performance, indirect ecosystem-level effects can also manifest, due to temperature altering trait-mediated processes. For example, increased temperature has been shown to increase feeding rates in some consumers, resulting in an increase in the strength of top-down regulation in food webs [65]. In the context of marine sedimentary ecology, studies have shown that changes in temperature can modify bioturbation rates. For example, White at al. reported a reduction in sediment reworking rates by $90 \%$ by oligochaetes due to a decline in temperature from 10 to $4{ }^{\circ} \mathrm{C}$ [66]. Ouelette et al. reported increased sediment transport by the polychaete Neanthes virens from cold $\left(1\right.$ and $\left.6{ }^{\circ} \mathrm{C}\right)$ to warm $\left(13\right.$ and $\left.18{ }^{\circ} \mathrm{C}\right)$ conditions [67]. Similarly, bioturbation activity of heart urchins and sediment re-working of a deposit-feeding bivalve increased with higher temperatures [68,69]. Lastly, mesocosm experiments on freshwater fish have reported increases in surface sediment disturbances with increases in temperature from 10 to $20^{\circ} \mathrm{C}$ [70].

In terms of thalassinideans, few studies have explored the effects of temperature on bioturbation rates. In one of the few studies of its kind, Berkenbusch and Rowden quantified rates of sediment expulsion from burrows of Biffarius (as Callianassa) filholi in an intertidal sandflat in New Zealand over a 12-month period and demonstrated a significant relationship between expulsion and temperature [59]. In particular, expulsion rates were greatest in summer and lowest in winter. This finding is consistent with the work of Rowden et al., who reported relative inactivity of Callianassa subterannea at low temperatures $\left(7^{\circ} \mathrm{C}\right)$, and lower sediment expulsion in spring and winter temperatures but higher levels in summer temperatures [16]. Thus, based on combined evidence from studies on thalassinids and other benthic ecosystem engineers, it is apparent that temperature can be a major determinant of sediment turnover activity, which is in turn a critical pathway by which engineering effects manifest at a biotic level. In addition, based on the above-mentioned studies, it would appear that within thermal limits, increasing temperatures are likely to lead to increased sediment turnover rates [66-70]. This, in turn, would lead to a general prediction or hypothesis that up to thermal optima, increasing temperatures would strengthen amensalistic effects generated by thalassinideans due to increased sediment reworking having stronger negative effects on epifauna and microbial biofilms. At a local level, this idea could additionally explain disparities in outcomes of South African exclusion experiments. Experiments conducted in Durban Bay, which is in a warm subtropical biogeographical region, identified very strong negative effects of Callichirus (as Callianassa) kraussi on microphytobenthic biomass and benthic macrofaunal community metrics, with strong amensalism detected on surface feeders [26,27]. In contrast, work in the Kasouga Estuary, which is in a warm-temperate bioregion, showed negligible effects of $C$. kraussi on microphytobenthos, community structure and metrics, with only one surface taxon being negatively affected [44]. Apart from biogeographical differences in temperature, thermal differences in these studies could additionally have arisen due to intertidal conditions in Durban Bay, with the benthos being subjected to warmer air temperatures during low tide.

Understanding the responses of benthic assemblages to ecosystem engineering by thalassinideans within the context of temperature variability is complicated by the fact that apart from influencing the engineers themselves, temperature can also directly influence sympatric assemblages. For example, studies elsewhere indicate that increasing temperature can induce stimulatory effects on microalgae [71]. If such positive temperature-driven effects on basal resources manifest in thalassinid-dominated sedimentary systems, then this can weaken amensalistic effects on surface fauna. This is because amensalism is thought to be driven, at least in part, by thalassinidean effects on trophic dynamics in surface sediments, due to turned over sediment either reducing trophic resources available to surface consumers or impairing feeding efficiency in filter-feeders by clogging feeding apparatus $[6,26,30]$. However, with increasing temperatures, bottom-up processes may strengthen, resulting potentially in higher trophic resource levels stimulating increases in surface grazer biomass. In terms of filter-feeders, similar effects may manifest due to increased resource availability in the form of phytoplankton. In addition, reductions in feeding rate due to turned over sediment interfering with filtration apparatus may be countered by higher phytoplankton availability. Lastly, if bacteria are stimulated by warming along with microalgae, then positive effects on microbial biofilms will likely emerge, thus stimulating 
colonisation and re-enforcing bottom-up trophic effects [29]. Infaunal responses to thalassinidean ecosystem engineering may also potentially be temperature-dependent. Increasing bioturbative activity due to rising temperatures suggests that sediment loosening would increase, thus favouring sympatric burrowers. In addition, if increased temperatures stimulate microalgal biomass [71], then positive effects on infauna will likely strengthen due to increased trophic resource levels within engineer burrows.

Apart from impacting basal resources, temperature can also modify the physiological processes of consumers in sympatric assemblages, over and above that of thalassinids. In terms of sympatric benthic invertebrates, processes such as reproduction, colonisation and feeding are all likely to be affected by temperature, with increasing temperature potentially having stimulatory effects on these processes, up to thermal optima [64]. This, together with the points made in the preceding paragraphs highlight the complexities that underlie predictions on how biotic responses to ecosystem engineering by thalassinideans are altered by increasing temperature. Collectively, this section demonstrates the need for a clear understanding of how temperature influences the strength of thalassinidean ecosystem engineering activities, the trophic environment and physiological processes of sympatric assemblages in order to confidently make predictions of temperature effects on thalassinid-dominated ecosystems.

\subsection{Productivity and Nutrients}

Productivity and nutrient levels (hereafter productivity for convenience) in marine sedimentary ecosystems vary across multiple spatial and temporal scales [72]. At a global level, productivity varies latitudinally, with higher chlorophyll levels and production rates at the equator and high latitudes [72]. Productivity also varies between upwelling and downwelling coastlines, but upwelling intensity also varies seasonally [73,74]. Moreover, human activities in coastal watersheds, mainly in the form of agricultural activities, influence land-aquatic runoff and hence productivity levels in coastal ecosystems [75]. At a global level, variation in background nutrient levels is thus potentially a significant contextual variable that determines how systems respond to engineering by thalassinidean crustaceans, based on studies elsewhere that have demonstrated the importance of productivity in determining ecosystem function and organismal interactions $[73,74]$.

Strengthening of bottom-up processes is one potential way in which increasing productivity can influence benthic community responses to thalassinideans. In thalassinid dominated sediments, such bottom-up effects are likely to occur not only at the sediment-water interface, but also deeper in sediments, due to overlying waters being actively pumped through burrows [6,54]. This would likely contrast with non-thalassinidean states, where bottom-up effects would probably manifest mainly at upper sediment layers. Therefore, one possible effect of increased water column productivity is that levels of trophic resources in burrow walls may increase, leading to stronger positive effects on infauna. Stronger facilitation of trophic resources in burrows with increasing productivity is likely to arise by blooming phytoplankton in overlying waters being adsorbed onto burrow walls during irrigation, or due to higher ambient nutrient levels magnifying thalassinid gardening activities. Increasing productivity is likely to also induce positive effects on epifauna, due to higher levels of surficial trophic resources. If this prediction is upheld, then increasing productivity would likely weaken amensalistic effects generated by thalassinids. In systems with lower productivity, sediment turnover by thalassinideans would probably reduce levels of microalgae, bacteria and other trophic resources available to consumers [6,29], accompanied by reduced surface consumer abundance due to resource limitation. However, this may be negated in more productive systems due to higher levels of trophic resources overcoming the amensalistic effects of sediment turnover, thus inducing stimulatory effects on surface consumers. In addition, metabolic costs incurred by filter-feeders due to turned over sediment impinging upon feeding time may be overcome by higher levels of ambient trophic resources. Thus, in systems with high productivity, thalassinidean ecosystem engineering is likely to generate stronger positive effects on infauna and weaker amensalistic effects on epifauna, assuming that differences in other biotic and abiotic variables are negligible. However, this prediction 
is complicated by the fact that nutrient addition experiments in marine sedimentary systems have had mixed results, with variable strengths of bottom-up effects reported [76-79]. In addition, shifts in microalgal community composition with increased nutrient levels can in some instances induce negative bottom-up effects [80].

Another dimension relevant to understanding how biotic responses to thalassinideans are altered by productivity is that productivity can theoretically influence thalassinid behavioural traits, which in turn has important implications for the strength of ecosystem engineering activities undertaken over-and-above the trophic effects outlined in the previous paragraph. This is an interesting idea that has been proposed previously [59], but is also one for which little empirical support exists. In an in situ study of sediment turnover rates, Berkenbusch and Rowden documented low turnover in low tide habitats inhabited by Biffarius (as Callianassa) filholi relative to sites further up the shore. Berkenbusch and Rowden suggested that in habitats where food availability is high, such as in the low shore where inundation times are high, the feeding rate of $B$. filholi may decrease due to high levels of trophic resources, causing sediment turnover rate to decline. If productivity does indeed alter thalassinid feeding traits and sediment turnover activities, as suggested by Berkenbusch and Rowden, then this mechanism needs to be considered along with the trophic effects highlighted in the preceding paragraph to develop a robust understanding of how productivity influences biotic responses to thalassinid ecosystem engineering.

\subsection{Community and Organismal-Level Traits}

Biological traits of sympatric assemblages are significant determinants of how they respond to disturbances induced by organisms $[47,61,62,81]$ but understanding of this aspect is limited in the context of thalassinidean ecosystem engineering. Sensitivity to disturbance is one such trait that can influence biotic responses to ecosystem engineering by thalassinideans. Classical theory suggests that assemblages dominated by $r$-selected species are able to tolerate high levels of disturbance due to physiological traits that allow for persistence under high disturbance levels and high colonisation rates that can offset disturbance-induced mortality. In contrast, assemblages dominated by K-selected organisms are disturbance sensitive due to traits that negatively predispose them to disturbances, such as slow colonisation and growth rates [62]. Thus, depending on whether assemblages under investigation are dominated by $r$ - or $\mathrm{K}$-selected organisms, which in turn is a product of background disturbance levels, biotic responses to thalassinideans may be very different. Outcomes may be weak or negligible if responding assemblages are disturbance tolerant (i.e., $r$-selected), but the opposite may be true for communities that are sensitive to disturbances (i.e., $K$-selected). This idea is supported by work on estuarine benthos, where it has been suggested that highly dynamic and/or frequently disturbed systems are dominated by a set of core species that persist under a range of abiotic and biotic states. Thus, disturbance induced shifts in abiotic conditions does not radically change species composition because of the disposition to withstand disturbance $[82,83]$.

At the level of individual species, behavioural traits and plasticity in those traits are also likely to influence responses to ecosystem engineering by thalassinideans, and can thus shed light on processes influencing variability in biotic responses to thalassinid engineering. This must also be viewed within the context of explanatory models in the field of thalassinid engineering research being largely trait-based. For example, the trophic-amensalism hypothesis [30] proposes that sediment reworking by deposit-feeders negatively affects surface suspension feeders due to resuspended sediment clogging filtration apparatus, leading to metabolic losses and potentially spatial displacement. Mobility and two-dimensional habitat utilisation within the sediment have also been invoked to explain organismal responses to thalassinideans, with sedentary surface groups being argued to be more affected by sediment turnover than mobile surface and infaunal groups [23]. However, the generality and applicability of these models to thalassinideans has been hindered by a limited understanding of behavioural traits and plasticity in responding organisms [6]. Studies have largely assumed the biological traits of response organisms based on morphology or studies elsewhere, without 
explicitly quantifying these traits. The problem with such an approach is that it ignores plasticity in behaviour, and hence the possibility that organisms may alter behaviour under different abiotic and biotic conditions. As shown by Needham et al., assigning biological and functional traits to organisms without understanding the plasticity thereof, runs the risk of oversimplifying complex organism-environment and organism-organism interactions [63]. In turn, this has implications for developing a predictive understanding of benthic responses to change [63], including that induced by thalassinidean ecosystem engineering. Thus, refining the understanding of biotic responses to thalassinidean engineering requires quantification of traits of responding organisms and the plasticity thereof under different contextual settings, including those highlighted in this review.

\subsection{Novel/Emerging Determinants of Thalassinidean Ecosystem Engineering}

The previous sections have alluded to the potential for variability in abiotic factors to impact the strength of biotic responses by altering trait-mediated processes influenced by thalassinids (principally sediment turnover). In this context, recent research has shed light on novel and less appreciated pathways by which trait-mediated processes involving thalassinideans can be affected. Studies by Dairain et al. for example, have shown that parasite and pollutant levels can influence the strength of thalassinidean ecosystem engineering [84]. Using a 14-day experiment in which parasitised (by the bopyrid isopod Gyge branchialis) and non-parasitised Upogebia cf. pusilla were exposed to cadmium contaminated and uncontaminated seawater, Dairain et al. demonstrated reductions in sediment reworking activity in parasitised Upogebia. Interestingly however, cadmium contamination elevated reworking [84]. This work raises the possibility that spatial variability in parasite and contaminant levels can impact the strength of abiotic modification, with potential ramifications for biotic assemblages.

In a different set of studies, Moyo et al. documented how interactions occurring within thalassinidean burrows can influence ecosystem engineering activities [85]. Using behavioural assessments, Moyo et al. highlighted complex processes and dependencies that influence the nature of interactions between the sandprawn Callichirus (as Callianassa) kraussi and a burrow symbiont, the alpheid shrimp Betaeus jucundus. Importantly, the outcomes of these interactions significantly influenced the amount of time spent by sandprawns on ecosystem engineering activities. Initial experiments indicated that sandprawn responses to B. jucundus were distinct, with individuals either tolerating the symbiont, semi-tolerating it, or being completely intolerant, in which case sandprawns ejected the symbiont out of burrows and sealed them. Importantly, intolerant sandprawns displayed a $50 \%$ increase in time spent on sediment turnover activities, but reduced time spent on irrigation by roughly $30 \%$. In a second experiment, it was shown that male and female sandprawns displayed contrasting behavioural responses to $B$. jucundus, with male sandprawns reducing time spent on sediment turnover in the presence of $B$. jucundus, though this was not evident in females. However, individuals of both sexes reduced the time spent on burrow irrigation activity in the presence of the burrow symbiont [84]. Thus, the results of these experiments put into perspective how little we know about interactions occurring within burrows between thalassinideans and symbionts, and how they can influence the strength of ecosystem engineering activities.

\section{Concluding Thoughts, Challenges and Directions for Future Research}

It should be apparent from this review that abiotic and biotic contexts have the potential to mediate biological responses to thalassinidean ecosystem engineering and to explain some of the variability in ecological responses evident in global research. This would suggest that rigorously understanding these processes is a logical step in building an integrative understanding of thalassinidean ecosystem engineering, which in turn requires that contextual processes be explicitly built into study designs in future. To date, studies on thalassinidean ecosystem engineering have focused on the role played by particular species as ecosystem engineers, in order to raise awareness of their ecological significance in coastal ecosystems [6]. While such research should in no way be depreciated, it must be understood that such studies provide a snapshot of the functional relevance of thalassinids within a subset of 
constrained ecological conditions. Thus, expanding future research by including contextual processes would provide a more robust understanding of thalassinidean ecosystem engineering under an expanded range of ecological settings. In this regard, testing the ideas, hypotheses and predictions proposed in this review may be an effective starting point to furthering research on contextual processes and dependencies that influence biotic responses. In addition, the contextual dependencies outlined in this review are by no means the totality of processes that can variably impact responses to thalassinideans. Thus, significant opportunities remain to unravel other processes and conditionalities that can refine understanding of how thalassinid engineering influences ecological processes. It must also be appreciated that the contextual processes highlighted in this review can interact in complex ways to mediate ecological responses; understanding such interactions thus present added opportunities to grow understanding of the processes that mediate responses to thalassinid engineering.

One of the major impediments to growing research on the contingencies that underpin thalassinid engineering is the logistical difficulties associated with working with endobenthic organisms. The great depth to which thalassinids burrow allied with their spatial spread complicates experimental designs due to the sheer amount of sediment that needs to be processed. It is not unrealistic for such experiments to require the processing of close to a ton of sediment, if not more. However, if we are to grow our understanding of the contextual processes underlying ecological responses to thalassinidean ecosystem engineering, creative and innovative approaches and methodologies are needed to deal with logistical constraints.

Greater research collaborations and linkages would likely expedite growth in our understanding of the contextual processes that determine responses to ecosystem engineering. Inter-institutional collaborations would probably be much more effective in quantifying and understanding drivers of response variability across the distribution range of particular thalassinid species than individual researcher contributions. In a similar vein, international collaborations can contribute to the growing understanding of contextual processes at a global level, with interspecific comparisons of engineering strength being a valuable contribution. In other marine ecosystems, multi-institutional collaborations have contributed to major disciplinary advances, shedding light on processes occurring at regional to global scales [73,86]. In this regard, there is much room for improvement in studies related to thalassinids as ecosystem engineers. It would be important for collaborative studies to pay particular attention to standardising methodologies and approaches, while obtaining robust data on ecological contexts that could be subjected to robust statistical analyses. It would be counter-productive for well-intended collaborative research to fail ultimately due to poor study designs and haphazard/unstructured data collection. In addition, explicit measurements of resources modulated in future studies (e.g., nutrient fluxes, sediment mixing) along with biotic response data could allow for the strength of propagating pathways to be quantified (e.g., [86]), thus shedding light on how interaction webs involving thalassinideans are altered by contextual processes.

While this review has advocated for further research on contextual processes that influence biotic responses to thalassinid ecosystem engineering, studies on individual thalassinidean species as ecosystem engineers have an important role to play in broadening understanding of engineering by this group. This is because of the roughly 550 thalassinid species described taxonomically [87], knowledge of their roles as ecosystem engineers is restricted to a smaller subset of species. Thus, paradigms regarding resource flow modulation and ecological responses are based on a limited set of studies across a narrow range of species [6]. Expanding engineer impact studies to broaden species bases for such studies therefore has significant potential to refine current understanding and identify novel propagating pathways and processes. Such studies could be rendered more valuable were contextual information explicitly collected to provide broader-scale perspective on findings. Importantly, such contextual information could be invaluable in future meta-analyses, thereby contributing indirectly to developing an understanding of contextual processes that influence thalassinid ecosystem engineering. Elsewhere, such approaches have progressively refined understanding of seminal ecological models [88-90] 
In view of the dynamic role played by thalassinid crustaceans in modifying sedimentary ecosystems [6], it is important that research on the group as ecosystem engineers does not stagnate. In this context, the ideas put forward in this review are intended to contribute to growth in the discipline, in the hope of generating new knowledge that can refine current understanding and re-shape existing paradigms. This is particularly relevant given the global distribution of thalassinid crustaceans and the intensity and scales to which they engineer ecosystems [6]. Generating new knowledge on thalassinid engineering assumes great significance when viewed in the context of challenges faced by ecosystem sciences and management due to added uncertainties imposed by global change. While the ideas expressed in this review are essentially driven by a need to improve fundamental scientific knowledge, some ideas have immediate linkages to global change topics. Understanding temperature effects on thalassinid ecosystem engineering, for example, is of relevance to understanding ecological responses to ocean warming. Similarly, nutrient effects on thalassinid engineering are directly relevant to understanding responses to coastal eutrophication. Therefore, some of the contextual processes identified in this review are relevant not only to clarifying variability in biotic responses to thalassinid engineering, but also for predicting ecological responses of thalassinid-dominated ecosystems to global change. Importantly, the latter aspect can be used as traction to garner funding to broaden research on engineering by thalassinideans, which in its own context, has generally struggled to attract funding. It is hoped that the perspectives expressed in this review will form a useful platform to grow research on thalassinid engineering so that ecologists and managers are ultimately able to predict ecological responses to these engineers under a broad range of ecological conditions and global change scenarios with increased confidence.

Funding: This work was supported by the National Research Foundation (NRF) of South Africa.

Conflicts of Interest: The author declares no conflict of interest.

\section{References}

1. Jones, C.G.; Lawton, J.H.; Shachak, M. Organisms as ecosystem engineers. Oikos 1994, 69, 373-386. [CrossRef]

2. Reise, K. Sediment mediated species interactions in coastal waters. J. Sea Res. 2002, 48, 127-141. [CrossRef]

3. Bouma, T.J.; Olenin, S.; Reise, K.; Ysebaert, T. Ecosystem engineering and biodiversity in coastal sediments: Posing hypotheses. Helgoland Mar. Res. 2009, 63, 96-106. [CrossRef]

4. Cadée, G.C. Sediment dynamics by bioturbating organisms. In Ecological Comparisons of Sedimentary Shores, Ecological Studies 151; Reise, K., Ed.; Springer: Berlin/Heidelberg, Germany, 2001; pp. 127-148.

5. Berkenbusch, K.; Rowden, A.A. Ecosystem engineering-Moving away from 'just-so' stories. N. Z. J. Ecol. 2003, 27, 67-73.

6. Pillay, D.; Branch, G.M. Bioengineering effects of burrowing thalassinidean shrimps on marine soft-bottom ecosystems. Oceanogr. Mar. Biol. Annu. Rev. 2011, 49, 137-192.

7. Poore, G.C.B. A phylogeny of the families of Thalassinidea (Crustacea: Decapoda) with keys to families and genera. Mem. Mus. Vic. 1994, 54, 79-120. [CrossRef]

8. Felder, D.L. Diversity and ecological significance of deep-burrowing macrocrustaceans in coastal tropical waters of the Americas (Decapoda: Thalassinidea). Intersciencia 2001, 26, 440-449.

9. Bracken, H.D.; Toon, A.; Felder, D.L.; Martin, J.W.; Finley, M.; Rasmussen, J.; Palero, F.; Crandall, K.A. The decapod tree of life: Compiling the data and moving toward a consensus of decapod evolution. Arthropod. Syst. Phylogeny 2009, 67, 99-116.

10. Robles, R.; Tudge, C.C.; Dworschak, P.C.; Poore, G.C.B.; Felder, D.L. Molecular phylogeny of the Thalassinidea based on nuclear and mitochondrial genes. In Decapod Crustacean Phylogenetics, Crustacean Issues 18; Martin, J.W., Crandall, K.A., Felder, D.L., Eds.; CRC Press: Boca Raton, FL, USA, 2009; pp. 309-326.

11. Papaspyrou, S.; Gregersen, T.; Cox, R.P.; Thessalou-Legaki, M.; Kristensen, E. Sediment properties and bacterial community in burrows of the ghost shrimp Pestarella tyrrhena (Decapoda: Thalassinidea). Aquat. Microb. Ecol. 2005, 38, 181-190. [CrossRef]

12. Pillay, D.; Branch, G.M.; Forbes, A.T. Habitat change in an estuarine embayment: Anthropogenic influences and a regime shift in biotic interactions. Mar. Ecol. Prog. Ser. 2008, 370, 19-31. [CrossRef] 
13. Pillay, D.; Williams, C.; Whitfield, A.K. Indirect effects of bioturbation by the burrowing sandprawn Callichirus kraussi on a benthic foraging fish, Liza richardsonii. Mar. Ecol. Prog. Ser. 2012, 453, 151-158. [CrossRef]

14. Koike, I.; Mukai, H. Oxygen and inorganic nitrogen contents and fluxes in burrows of the shrimps Callianassa japonica and Upogebia major. Mar. Ecol. Prog. Ser. 1983, 12, 185-190. [CrossRef]

15. Ziebis, W.; Forster, S.; Huettel, M.; Jørgensen, B.B. Complex burrows of the mud shrimp Callianassa truncata and their geochemical impact in the sea bed. Nature 1996, 382, 619-622. [CrossRef]

16. Rowden, A.A.; Jones, M.B.; Morris, A.W. The role of Callianassa subterranea (Montagu) (Thalassinidea) in sediment resuspension in the North Sea. Cont. Shelf Res. 1998, 18, 1365-1380. [CrossRef]

17. Flach, E.; Tamaki, A. Competitive bioturbators on intertidal sand flats in the European Wadden Sea and Ariake Sound in Japan. In Ecological Comparisons of Sedimentary Shores, Ecological Studies 151; Reise, K., Ed.; Springer: Berlin, Germany, 2001; pp. 276-293.

18. D'Andrea, A.F.; DeWitt, T.H. Geochemical ecosystem engineering by the mud shrimp Upogebia pugettensis (Crustacea: Thalassinidae) in Yaquina Bay, Oregon: Density-dependent effects on organic matter remineralization and nutrient cycling. Limnol. Oceanogr. 2009, 54, 1911-1932. [CrossRef]

19. Volkenborn, N.; Polerecky, L.; Wethey, D.S.; DeWitt, T.H.; Woodin, S.A. Hydraulic activities by ghost shrimp Neotrypaea californiensis induce oxic- anoxic oscillations in sediments. Mar. Ecol. Progr. Ser. 2012, 455, 141-156. [CrossRef]

20. Pascal, L.; Maire, O.; Volkenborn, N.; Lecroart, P.; Bichon, S.; de Montaudouin, X.; Grémare, A.; Deflandre, B. Influence of the mud shrimp Upogebia pusilla (Decapoda: Gebiidea) on solute and porewater exchanges in an intertidal seagrass (Zostera noltei) meadow of Arcachon Bay: An experimental assessment. J. Exp. Mar. Biol. Ecol. 2016, 477, 69-79. [CrossRef]

21. Aller, R.C.; Dodge, R.E. Animal-sediment relations in a tropical lagoon Discovery Bay, Jamaica. J. Mar. Res. 1974, 32, 209-232.

22. Peterson, C.H. Competitive organization of the softbottom macrobenthic communities of Southern California lagoons. Mar. Biol. 1977, 43, 343-359. [CrossRef]

23. Brenchley, G.A. Disturbance and community structure: An experimental study of bioturbation in marine soft-bottom environments. J. Mar. Res. 1981, 39, 767-790.

24. Murphy, R.C. Factors affecting the distribution of the introduced bivalve, Mercenaria mercenaria, in a California lagoon-The importance of bioturbation. J. Mar. Res. 1985, 43, 673-692. [CrossRef]

25. Posey, M.H.; Dumbauld, B.R.; Armstrong, D.A. Effects of a burrowing mud shrimp, Upogebia pugettensis (Dana), on abundances of macro-infauna. J. Exp. Mar. Biol. Ecol. 1991, 148, 283-294. [CrossRef]

26. Pillay, D.; Branch, G.M.; Forbes, A.T. The influence of bioturbation by the sandprawn Callianassa kraussi on feeding and survival of the bivalve Eumarcia paupercula and the gastropod Nassarius kraussianus. J. Exp. Mar. Biol. Ecol. 2007, 344, 1-9. [CrossRef]

27. Pillay, D.; Branch, G.M.; Forbes, A.T. Experimental evidence for the effects of the thalassinidean sandprawn Callianassa kraussi on macrobenthic communities. Mar. Biol. 2007, 152, 611-618. [CrossRef]

28. Flach, E.C. The distribution of the amphipod Corophium arenarium in the Dutch Wadden Sea: Relationships with sediment composition and the presence of cockles and lugworms. Neth. J. Sea Res. 1993, 31, 281-290. [CrossRef]

29. Pillay, D.; Branch, G.M.; Forbes, A.T. Effects of Callianassa kraussi on microbial biofilms and recruitment of macrofauna: A novel hypothesis for adult-juvenile interactions. Mar. Ecol. Prog. Ser. 2007, 347, 1-14. [CrossRef]

30. Rhoads, D.C.; Young, D.K. The influence of deposit-feeding organisms on sediment stability and community trophic structure. J. Mar. Res. 1970, 28, 150-178.

31. Siebert, T.; Branch, G.M. Interactions between Zostera capensis and Callianassa kraussi: Influences on community composition of eelgrass beds and sandflats. Afr. J. Mar. Sci. 2005, 27, 357-373. [CrossRef]

32. Siebert, T.; Branch, G.M. Interactions between Zostera capensis, Callianassa kraussi and Upogebia africana: Deductions from field surveys in Langebaan Lagoon, South Africa. Afr. J. Mar. Sci. 2005, 27, 345-356. [CrossRef]

33. Siebert, T.; Branch, G.M. Ecosystem engineers: Interactions between eelgrass Zostera capensis and the sandprawn Callianassa kraussi and their indirect effects on the mudprawn Upogebia africana. J. Exp. Mar. Biol. Ecol. 2006, 338, 253-270. [CrossRef] 
34. Siebert, T.; Branch, G.M. Influences of biological interactions on community structure within seagrass beds and sandprawn-dominated sandflats. J. Exp. Mar. Biol. Ecol. 2007, 340, 11-24. [CrossRef]

35. Pillay, D.; Branch, G.M.; Dawson, J.; Henry, D. Contrasting effects of ecosystem engineering by the cordgrass Spartina maritima and the sandprawn Callianassa kraussi in a marine-dominated lagoon. Est. Coast. Shelf Sci. 2011, 91, 169-176. [CrossRef]

36. Branch, G.M.; Pringle, A. The impact of the sand prawn Callianassa kraussi Stebbing on sediment turnover and on bacteria, meiofauna, and benthic microflora. J. Exp. Mar. Biol. Ecol. 1987, 107, 219-235. [CrossRef]

37. Dobbs, F.C.; Guckert, J.B. Callianassa trilobata (Crustacea: Thalassinidea) influences abundance of meiofauna and biomass, composition, and physiologic state of microbial communities within its burrow. Mar. Ecol. Prog. Ser. 1988, 45, 69-79. [CrossRef]

38. Dworschak, P.C. The burrows of Callianassa tyrrhena (Petagna 1792) (Decapoda: Thalassinidea). Mar. Ecol. 2001, 22, 155-166. [CrossRef]

39. Bird, F.L.; Boon, P.I.; Nichols, P.D. Physicochemical and microbial properties of burrows of the deposit-feeding thalassinidean ghost shrimp Biffarius arenosus (Decapoda: Callianassidae). Est. Coast. Shelf Sci. 2000, 51, 279-291. [CrossRef]

40. Alongi, D.M. Effect of physical disturbance on population dynamics and trophic interactions among microbes and meiofauna. J. Mar. Res. 1985, 43, 351-364. [CrossRef]

41. Dittmann, S. Effects of macrobenthic burrows on infaunal communities in tropical tidal flats. Mar. Ecol. Prog. Ser. 1996, 134, 119-130. [CrossRef]

42. Suchanek, T.H. Control of seagrass communities and sediment distribution by Callianassa (Crustacea, Thalassinidea) bioturbation. J. Mar. Res. 1983, 41, 281-298. [CrossRef]

43. Bird, F.L. The interaction between ghost shrimp activity and seagrass restoration. In Proceedings of the Symposium on Ecology of Large Bioturbators in Tidal Flats and Shallow Sublittoral Sediments-From Individual Behaviour to Their Role as Ecosystem Engineers; Tamaki, A., Ed.; Nagasaki University: Nagasaki, Japan, 2004; pp. 71-75.

44. Henninger, T.O.; Froneman, P.W. Role of the sandprawn Callichirus kraussi as an ecosystem engineer in a South African temporarily open/closed estuary. Afr. J. Aquat. Sci. 2013, 38, 101-107. [CrossRef]

45. Jones, C.G.; Lawton, J.H.; Shachak, M. Positive and negative effects of organisms as physical ecosystem engineers. Ecology 1997, 78, 1946-1957. [CrossRef]

46. Lohrer, A.M.; Thrush, S.F.; Gibbs, M.M. Bioturbators enhance ecosystem function through complex biogeochemical interactions. Nature 2004, 431, 1092-1095. [CrossRef] [PubMed]

47. Schmitz, O.J.; Krivan, V.; Ovadia, O. Trophic cascades: The primacy of trait-mediated indirect interactions. Ecol. Lett. 2004, 7, 153-163. [CrossRef]

48. Bouma, T.J.; DeVries, M.B.; Low, E.; Peralta, G.; Tánczos, I.V.; van de Koppel, J.; Herman, P.J. Trade-offs related to ecosystem engineering: A case study on stiffness of emerging macrophytes. Ecology 2005, 86, 2187-2199. [CrossRef]

49. Nates, S.F.; Felder, D.L. Impact of burrowing ghost shrimp, Genus Lepidophthalmus Crustacea: Decapoda: Thalassinidea, on penaeid shrimp culture. J. World Aquac. Soc. 1998, 29, 188-210. [CrossRef]

50. Shy, J.; Chan, T. Complete larval development of the edible mud shrimp Upogebia edulis Ngoc-Ho \& Chan, 1992 (Decapoda, Thalassinidea, Upogebiidae) reared in the laboratory. Crustaceana 1996, 69, 175-186.

51. Forbes, A.T. An unusual abbreviated larval life in the estuarine prawn Callianassa kraussi (Crustacea: Decapoda: Thalassinidea). Mar. Biol. 1973, 22, 361-365. [CrossRef]

52. Coelho, V.R. Feeding behaviour, morphological adaptations and burrowing in thalassinidean crustaceans. In Proceedings of the Symposium on Ecology of Large Bioturbators in Tidal Flats and Shallow Sublittoral Sediments-From Individual Behaviour to Their Role as Ecosystem Engineers; Tamaki, A., Ed.; Nagasaki University: Nagasaki, Japan, 2004; pp. 1-6.

53. Abed-Navandi, D.; Dworschak, P.C. Food sources of tropical thalassinidean shrimps: A stable-isotope study. Mar. Ecol. Prog. Ser. 2005, 291, 159-168. [CrossRef]

54. Atkinson, R.J.A.; Taylor, A.C. Aspects of the physiology, biology and ecology of thalassinidean shrimps in relation to their burrow environment. Oceanogr. Mar. Biol. Annu. Rev. 2005, 43, 173-210.

55. Shimoda, K.; Aramaki, Y.; Nasuda, J.; Yokoyama, H.; Ishihi, Y.; Tamaki, A. Food sources for three species of Nihonotrypaea (Decapoda: Thalassinidea: Callianassidae) from western Kyushu, Japan, as determined by carbon and nitrogen stable isotope analysis. J. Exp. Mar. Biol. Ecol. 2007, 342, 292-312. [CrossRef] 
56. Griffis, R.B.; Chavez, F.L. Effects of sediment type on burrows of Callianassa californiensis Dana and C. gigas Dana. J. Exp. Mar. Biol. Ecol. 1988, 117, 239-253. [CrossRef]

57. Dworschak, P.C. Biology of Mediterranean and Caribbean Thalassinidea. In Proceedings of the Symposium on Ecology of Large Bioturbators in Tidal Flats and Shallow Sublittoral Sediments_From Individual Behaviour to Their Role as Ecosystem Engineers; Tamaki, A., Ed.; Nagasaki University: Nagasaki, Japan, 2004; pp. 15-22.

58. Nickell, L.A.; Atkinson, R.J.A. Functional morphology of burrows and trophic modes of three thalassinidean shrimp species, and a new approach to the classification of thalassinidean burrow morphology. Mar. Ecol. Prog. Ser. 1995, 128, 181-197. [CrossRef]

59. Berkenbusch, K.; Rowden, A.A. Factors influencing sediment turnover by the burrowing ghost shrimp Callianassa filholi (Decapoda: Thalassinidea). J. Exp. Mar. Biol. Ecol. 1999, 238, 283-292. [CrossRef]

60. Rowden, A.A.; Jones, M.B. Critical evaluation of sediment turnover estimates for Callianassidae (Decapoda: Thalassinidea). J. Exp. Mar. Biol. Ecol. 1993, 173, 265-272. [CrossRef]

61. Little, C.; Little, E.C.S. The Biology of Soft Shores and Estuaries; Oxford University Press: Oxford, UK, 2000.

62. Raffaelli, D.; Hawkins, S.J. Intertidal Ecology; Springer Science \& Business Media: Berlin/Heidelberg, Germany, 2012.

63. Needham, H.R.; Pilditch, C.A.; Lohrer, A.M.; Thrush, S.F. Context-specific bioturbation mediates changes to ecosystem functioning. Ecosystems 2011, 14, 1096-1109. [CrossRef]

64. Withers, P.C. Comparative Animal Physiology; Brooks/Cole: Boston, MA, USA, 1992.

65. Carr, L.A.; Bruno, J.F. Warming increases the top-down effects and metabolism of a subtidal herbivore. PeerJ 2013, 1, e109. [CrossRef] [PubMed]

66. White, D.S.; Klahr, P.C.; Robbins, J.A. Effects of temperature and density on sediment reworking by Stylodrilus heringianus (Oligochaeta: Lumbriculidae). J. Great Lakes Res. 1987, 13, 147-156. [CrossRef]

67. Ouellette, D.; Desrosiers, G.; Gagne, J.P.; Gilbert, F.; Poggiale, J.C.; Blier, P.U.; Stora, G. Effects of temperature on in vitro sediment reworking processes by a gallery biodiffusor, the polychaete Neanthes virens. Mar. Ecol. Prog. Ser. 2004, 266, 185-193. [CrossRef]

68. Hollertz, K.; Duchêne, J.C. Burrowing behaviour and sediment reworking in the heart urchin Brissopsis lyrifera Forbes (Spatangoida). Mar. Biol. 2001, 139, 951-957.

69. Maire, O.; Duchene, J.C.; Gremare, A.; Malyuga, V.S.; Meysman, F.J.R. A comparison of sediment reworking rates by the surface deposit-feeding bivalve Abra ovata during summertime and wintertime, with a comparison between two models of sediment reworking. J. Exp. Mar. Biol. Ecol. 2007, 343, 21-36. [CrossRef]

70. Canal, J.; Laffaille, P.; Gilbert, F.; Lauzeral, C.; Buisson, L. Influence of temperature on surface sediment disturbance by freshwater fish: A microcosm experiment. Ann. Limnol. Int. J. Lim. 2015, 51, 179-188. [CrossRef]

71. Baranov, V.; Lewandowski, J.; Krause, S. Bioturbation enhances the aerobic respiration of lake sediments in warming lakes. Biol. Lett. 2016, 12, 20160448. [CrossRef] [PubMed]

72. Sigman, D.M.; Hain, M.P. The Biological Productivity of the Ocean. Nat. Educ. Knowl. 2012, 3, 21.

73. Bustamante, R.H.; Branch, G.M.; Eekhout, S.; Robertson, B.; Zoutendyk, P.; Schleyer, M.; Dye, A.; Hanekom, N.; Keats, D.; Jurd, M.; et al. Gradients of intertidal primary productivity around the coast of South Africa and their relationships with consumer biomass. Oecologia 1995, 102, 189-201. [CrossRef]

74. Bustamante, R.H.; Branch, G.M.; Eekhout, S. Maintenance of an exceptional intertidal grazer biomass in South Africa: Subsidy by subtidal kelps. Ecology 1995, 76, 2314-2329. [CrossRef]

75. Kemp, W.M.; Boynton, W.R.; Adolf, J.E.; Boesch, D.F.; Boicourt, W.C.; Brush, G.; Cornwell, J.C.; Fisher, T.R.; Glibert, P.M.; Hagy, J.D.; et al. Eutrophication of Chesapeake Bay: Historical trends and ecological interactions. Mar. Ecol. Prog. Ser. 2005, 303, 1-29. [CrossRef]

76. Widbom, B.; Elmgren, R. Response of benthic meiofauna to nutrient enrichment of experimental marine ecosystems. Mar. Ecol. Prog. Ser. 1988, 24, 257-268. [CrossRef]

77. Posey, M.H.; Alphin, T.D.; Cahoon, L.; Lindquist, D.; Becker, M.E. Interactive effects of nutrient additions and predation on infaunal communities. Estuaries 1999, 22, 785-792. [CrossRef]

78. Posey, M.H.; Alphin, T.D.; Cahoon, L.B.; Lindquist, D.; Mallin, M.A.; Nevers, M.B. Top-down versus bottom-up limitation in benthic infaunal communities: Direct and indirect effects. Estuaries 2002, 25, 999-1014. [CrossRef] 
79. Hamilton, D.J.; Diamond, A.W.; Wells, P.G. Shorebirds, snails, and the amphipod Corophium volutator in the upper Bay of Fundy: Top-down vs. bottom-up factors, and the influence of compensatory interactions on mudflat ecology. Hydrobiologia 2006, 567, 285-306. [CrossRef]

80. Armitage, A.R.; Fong, P. Upward cascading effects of nutrients: Shifts in a benthic microalgal community and a negative herbivore response. Oecologia 2004, 139, 560-567. [CrossRef] [PubMed]

81. Little, C.; Kitching, J.A. The Biology of Rocky Shores; Oxford University Press: New York, NY, USA, 1996.

82. MacKay, F.; Cyrus, D.; Russell, K.L. Macrobenthic invertebrate responses to prolonged drought in South Africa's largest estuarine lake complex. Est. Coast. Shelf Sci. 2010, 86, 553-567. [CrossRef]

83. Pillay, D.; Bowns, S.; Nel, H. Benthic Fauna. In Ecology and Conservation of Estuarine Ecosystems: Lake St. Lucia as a Global Model; Perissinotto, R., Stretch, D., Taylor, R., Eds.; Cambridge University Press: Cambridge, UK, 2013; pp. 226-245.

84. Dairain, A.; de Montaudouin, X.; Gonzalez, P.; Ciutat, A.; Baudrimont, M.; Maire, O.; Legeay, A. Do trace metal contamination and parasitism influence the activities of the bioturbating mud shrimp Upogebia cf. pusilla? Aquat. Toxicol. 2018, 204, 46-58. [CrossRef] [PubMed]

85. Moyo, R.; Pillay, D.; Baeza, J.A. Symbiont-mediated shifts in sandprawn behaviour: Implications for ecosystem functioning in marine soft-sediment ecosystems. J. Exp. Mar. Biol. Ecol. 2017, 486, 296-304. [CrossRef]

86. Thrush, S.F.; Hewitt, J.E.; Parkes, S.; Lohrer, A.M.; Pilditch, C.; Woodin, S.A.; Wethey, D.S.; Chiantore, M.; Asnaghi, V.; De Juan, S.; et al. Experimenting with ecosystem interaction networks in search of threshold potentials in real-world marine ecosystems. Ecology 2014, 95, 1451-1457. [CrossRef] [PubMed]

87. Dworschak, P.C. Global diversity in the Thalassinidea (Decapoda): An update (1998-2004). Nauplius 2005, 13, 57-63.

88. Borer, E.T.; Seabloom, E.W.; Shurin, J.B.; Anderson, K.E.; Blanchette, C.A.; Broitman, B.; Cooper, S.D.; Halpern, B.S. What determines the strength of a trophic cascade? Ecology 2005, 86, 528-537. [CrossRef]

89. Shurin, J.B.; Borer, E.T.; Seabloom, E.W.; Anderson, K.; Blanchette, C.A.; Broitman, B.; Cooper, S.D.; Halpern, B.S. A cross-ecosystem comparison of the strength of trophic cascades. Ecol. Lett. 2002, 5, 785-791. [CrossRef]

90. Mackey, R.L.; Currie, D.J. The diversity-disturbance relationship: Is it generally strong and peaked? Ecology 2001, 82, 3479-3492. 